\title{
EVALUATION OF PITCHES AND COKES FROM SOLVENT-EXTRACTED COAL MATERIALS
}

\section{FINAL REPORT}

August 7, 1995 To August 6, 1996

\author{
Report Prepared by \\ E. R. McHenry \\ Koppers Industries Inc. \\ Harmarville Technical Center \\ 1005 Wm. Pitt Way \\ Pittsburgh, PA 15238 \\ under \\ Subcontract 86X-SS131V, WBS Element Koppers - 3 \\ for \\ OAK RIDGE NATIONAL LABORATORY \\ Oak Ridge, Tennessee 37831 \\ Managed by \\ LOCKHEED MARTIN ENERGY RESEARCH CORP. \\ For the \\ U. S. DEPARTMENT OF ENERGY \\ under contract DE-AC05-960R22464
}




\section{DISCLAIMER}

This report was prepared as an account of work sponsored by an agency of the United States Government. Neither the United States Government nor any agency thereof, nor any of their employees, make any warranty, express or implied, or assumes any legal liability or responsibility for the accuracy, completeness, or usefulness of any information, apparatus, product, or process disclosed, or represents that its use would not infringe privately owned rights. Reference herein to any specific commercial product, process, or service by trade name, trademark, manufacturer, or otherwise does not necessarily constitute or imply its endorsement, recommendation, or favoring by the United States Government or any agency thereol. The views and opinions of authors expressed herein do not necessarily state or reflect those of the United States Government or any agency thereof. 


\section{DISCLAMMER}

Portions of this document may be illegible in electronic image products. Images are produced from the best available original document. 


\section{SUMMARY}

Three initial coal-extracted (C-E) samples were received from the West Virginia University (WVU) Chemical Engineering Department. Two samples had been hydrogenated to obtain pitches that satisfy rheological requirements. One of the hydrogenated (HC-E) samples had been extracted by toluene to remove ash and higher molecular weight aromatic compounds.

We were unable to measure the softening point and viscosity of the non-hydro treated solid extract sample. Positive characteristics in the HC-E materials were softening points of $113-119^{\circ} \mathrm{C}$, low sulfur and ash. The oxygen and nitrogen content of the HC-E samples may limit future usage in premium carbon and graphite products. Coking values were similar to petroleum pitches.

Laboratory anode testing indicates that in combination with standard coal-tar pitch, the HC-E material can be used as a binder pitch.

\section{INTRODUCTION}

The closure of by-product coal coking oven batteries has resulted in up to a $3 \%$ per annum reduction in domestic coal-tar production during the middle of the 1990's. This source reduction has affected industrial capability to produce quantities of quality of binder and impregnating pitches used in the aluminum and commercial carbon and graphite industries. The objectives of this research are to develop dependable domestic coal-based raw materials for the production of: binder pitches for aluminum cell anodes and commercial carbon and graphite products; impregnating pitches for commercial carbon and graphite products and specialty materials; oils for wood treatment and carbon black production; and metallurgical and foundry grade cokes. 
We reviewed the processing and product properties of the coal extract materials prepared by WVU. The WVU coal extraction process coupled with hydrogenation yields materials that have potential binder and impregnation application.

We performed standard characterization of small-scale extracts. This information was shared with our Carbon Products Consortium (CPC) partners (Alcoa, Amoco, Conoco, FMI, UCAR and WWU). We also formed small carbon artifacts to demonstrate the binding capability of the laboratory-extracted pitches.

Our studies are summarized in the following sections of this report.

\section{EXPERIMENTAL PROCEDURES}

A. Pitch property measurement methods as measured by Koppers are listed in Table I.

Table I

Methods for Measuring Pitch Properties

\begin{tabular}{|c|c|c|}
\hline Characterization & Unit & Method \\
\hline Softening Point (sp) & ${ }^{\circ} \mathrm{C}$ & ASTM D 3104 (Mettler) \\
\hline Viscosity & $\mathrm{cP}$ & ASTM D 5018 \\
\hline Toluene Insoluble (TI) & wt. \% & ASTM D 4072 \\
\hline Quinoline Insoluble (QI) & wt. \% & ASTM D 2318 or D 4746 \\
\hline$\beta-\operatorname{Resin}(\beta-R)$ & wt. \% & $\mathrm{TI}-\mathrm{QI}$ \\
\hline $\begin{array}{c}\text { Modified Conradson Carbon } \\
\text { Coking Value (MCC) }\end{array}$ & wt. \% & ASTM D 2416 \\
\hline Density, $25^{\circ} \mathrm{C}$ & $\mathrm{g} / \mathrm{cm}^{3}$ & $\begin{array}{l}\text { ASTM D } 71 \text { (Water) or } \\
\text { D } 4892 \text { (Helium) }\end{array}$ \\
\hline Ash & wt. \% & ASTM D 2415 \\
\hline Carbon and Hydrogen & wt. \% & LECO CHN Analyzer \\
\hline Elemental Analysis & $\mathrm{ppm}$ & $\begin{array}{l}\text { Atomic Absorbtion (ASTM Draft } \\
\text { Method) }\end{array}$ \\
\hline Sulfur & wt. \% & LECO Sulfur Analyzer \\
\hline Thermogravimetric Analysis (TGA) & & $\begin{array}{l}\text { UCAR, using TA Instruments } \\
\text { Model } 951 \text { Module }\left(10^{\circ} \mathrm{C} / \mathrm{min} \text {. in }\right. \\
\text { inert atmosphere })\end{array}$ \\
\hline
\end{tabular}


B. Bench-Scale Anode Production

1. Raw Materials

a) Sized petroleum coke provided by a commercial aluminum smelter.

b) Experimental and commercial pitches.

2. Mix Design as Provided by a Commercial Smelter.

3. Forming Conditions ( $50 \mathrm{~mm}$-diameter mold)
a) $185^{\circ} \mathrm{C}$ mixing temperature
b) $105^{\circ} \mathrm{C}$ molding
c) 7500 psi molding pressure

4. $1150^{\circ} \mathrm{C}$ Maximum Baking Temperature

a) $10^{\circ} \mathrm{C} / \mathrm{Hr} 0-600^{\circ} \mathrm{C}$

b) $25^{\circ} \mathrm{C} / \mathrm{Hr} 600-1150^{\circ} \mathrm{C}$

c) 13 -Hour hold at $1150^{\circ} \mathrm{C}$

(Inert gas purge throughout baking and cooling cycle.)

\section{Anode Testing}

Carbon anode testing methods at Koppers are detailed and supported by established quality control procedures. Koppers is directly involved in establishing carbon testing methods in ASTM and ISO; consequently, these methods or methods-under-development are used wherever possible. Statistical process control is used at each test station. A list of our typical testing methods with units is summarized in Table II.

Table II

Carbon Anode Property Measurements

\begin{tabular}{|l|c|}
\hline \multicolumn{1}{|c|}{ Characterization } & Unit \\
\hline Apparent Density & $\mathrm{g} / \mathrm{cm}^{3}$ \\
\hline Electrical Resistivity & $\mu \Omega \mathrm{m}$ \\
\hline Air Permeability & $\mathrm{nPm}$ \\
\hline Compressive Strength & $\mathrm{Mpa}$ \\
\hline Coefficient of Thermal Expansion to $300^{\circ} \mathrm{C}$ & $10^{-5} /{ }^{\circ} \mathrm{C}$ \\
\hline Thermal Conductivity & $\mathrm{W} / \mathrm{m}-{ }^{\circ} \mathrm{K}$ \\
\hline
\end{tabular}

IV. EXPERIMENTAL RESULTS

A. Initial WUU Coal Extract Sample Study

Three initial coal-extracted samples were received from WVU. The first extract sample was hydro-treated to form Sample No. 2. Sample No. 3 represents the toluene-extract from Sample No. 2. Our analyses are summarized in Table III. 
Table III

Analyses of Three Coal Extract Samples from WVU

\begin{tabular}{|c|c|c|c|}
\hline Sample No. & 1 & 2 & 3 \\
\hline & $\begin{array}{l}\text { Solvent Extracted Residue } \\
\text { from Coal }\end{array}$ & $\begin{array}{c}\text { Hydrogenated Sample } \\
1\end{array}$ & $\begin{array}{c}\text { Toluene-Extracted Material } \\
\text { from Sample } 2\end{array}$ \\
\hline $\mathrm{SP},{ }^{\circ} \mathrm{C}$ & Not Analyzed & 119.2 & 112.8 \\
\hline TI, wt.\% & 92.7 & 11.5 & 1.3 \\
\hline QI, wt.\% & 2.4 & 0.5 & 0.02 \\
\hline$\beta-R, w t . \%$ & 90.3 & 11.0 & 1.28 \\
\hline Density $\left(25^{\circ} \mathrm{C}\right) \mathrm{g} / \mathrm{cm}^{3}$ & 1.272 & 1.206 & 1.217 \\
\hline Ash, wt. $\%$ & .25 & 0.07 & 0.0 \\
\hline MCC, wt. \% & NA & 50.7 & 44.8 \\
\hline $\mathrm{C} / \mathrm{H}, \mathrm{wt} . \%$ & 1.35 & 1.31 & 1.23 \\
\hline C, wt. \% & 89.97 & 89.57 & 88.84 \\
\hline H, wt. \% & 5.88 & 5.72 & 6.04 \\
\hline $\mathrm{N}$, wt. $\%$ & 2.09 & 2.04 & 1.72 \\
\hline O, wt. \% & 1.32 & 2.06 & 2.67 \\
\hline S, wt. \% & 0.74 & 0.37 & 0.42 \\
\hline \multicolumn{4}{|l|}{ Viscosity, cps: } \\
\hline$@ 150^{\circ} \mathrm{C}$ & Not Analyzed & 12,160 & 2395 \\
\hline$@ 160^{\circ} \mathrm{C}$ & Not Analyzed & 2,430 & 909 \\
\hline$@ 180^{\circ} \mathrm{C}$ & Not Analyzed & 430 & 209 \\
\hline$@ 200^{\circ} \mathrm{C}$ & Not Analyzed & 150 & 72 \\
\hline
\end{tabular}


Sample Nos. 2 and 3 have softening points and viscosities that will enable use as binders or impregnants. The sulfur, ash and $\mathrm{Q} I$ are sufficiently low for use as an impregnant. The coking value reflects the low QI levels and aromaticity. The oxygen and nitrogen levels are higher than desirable; however, these levels are lower than in most mild gasification pitch type materials.

The TGA data in Figures 1 and 2 were measured by our CPC partner, UCAR. These results are similar to earlier samples produced at WWU for a UCAR study. ${ }^{1}$ This illustrates repeatable bench-scale production at WVU.

\section{B. Bench-Scale Anode Study}

Because we only had about 500 grams each of the HC-E pitches, it was decided to perform a limited bench-scale anode forming study. We used $110^{\circ} \mathrm{C}$ sp coal-tar pitch (P-1) and petroleum pitch (P-2) as controls. The primary trial pitch was the No. $2 \mathrm{HC}-\mathrm{E} 119^{\circ} \mathrm{C}$ sp sample and was labeled P-3.

In order to explore an alternate approach of the trial material, a 20\% HC-E P3 pitch blend was made with the standard coal-tar pitch. The analyses of the control and trial binder pitches are compared in Table IV. With the 20/80 P-4 blend we have achieved typical binder pitch properties.

Following the guidelines outlined in the Experimental Procedure Section, 50 $\mathrm{mm}$ diameter $\mathrm{x} \sim 120 \mathrm{~mm}$ anodes were formed with the four pitches. Because this was new molding equipment, optimum binder levels were unknown. The trial pitch quantities only permitted the forming of a single anode at each different binder level. Two anodes were formed at each binder level for the control pitches.

The baked carbon test data are summarized in Table $V$ and Figures 3-9. The optimum binder may have been obtained for the petroleum pitch via the 15$16 \%$ range; however, the other three pitches require more anode forming at higher percentage levels. The baked density and other properties show that more work is required to complete this study. The property trends provide encouragement for additional larger-scale anode evaluations.

1I. C. Lewis, R. T. Lewis and H. K. Mayer, "Coal Precursors for Production of Carbon and Graphite Products - Final Report" Subcontract 62X-SR928C, WBS Element - UCAR-3, April 8, 1996. 
Sample: R95-1498 (D057-2)

Size: $\quad 25.3470 \mathrm{mg}$

Method: $10 \mathrm{C} / \mathrm{MIN}$

Comment: ARGON 100CC/MIN Pt PAN TGA \#5904

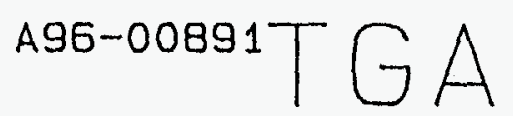

File: C: $96030401 \mathrm{~A} .03$

Operator: gfl

Run Date: 5-Mar-96 12: 56

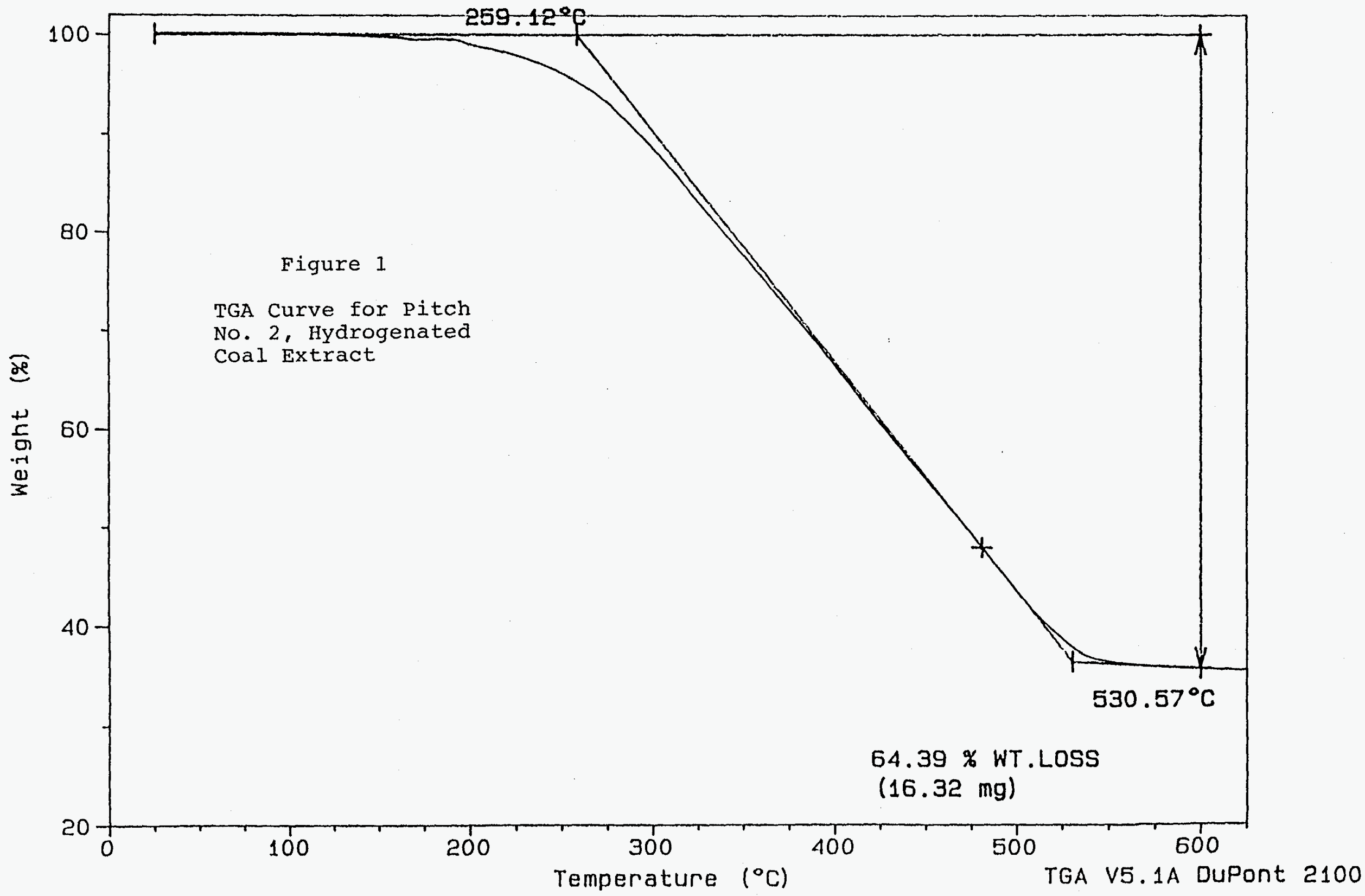


Sample: R95-1499 (D057-3) Size: $25.1250 \mathrm{mg}$

Method: $10 \mathrm{C} / \mathrm{MIN}$

Comment: ARGON 100CC/MIN

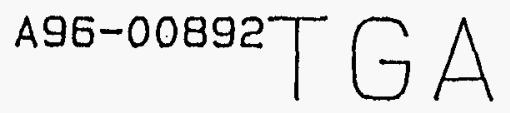

Pt PAN TGA \#5904
File: C: $96030401 \mathrm{~B} .02$

Operator: gfl

Run Date: 5-Mar-96 08: 27

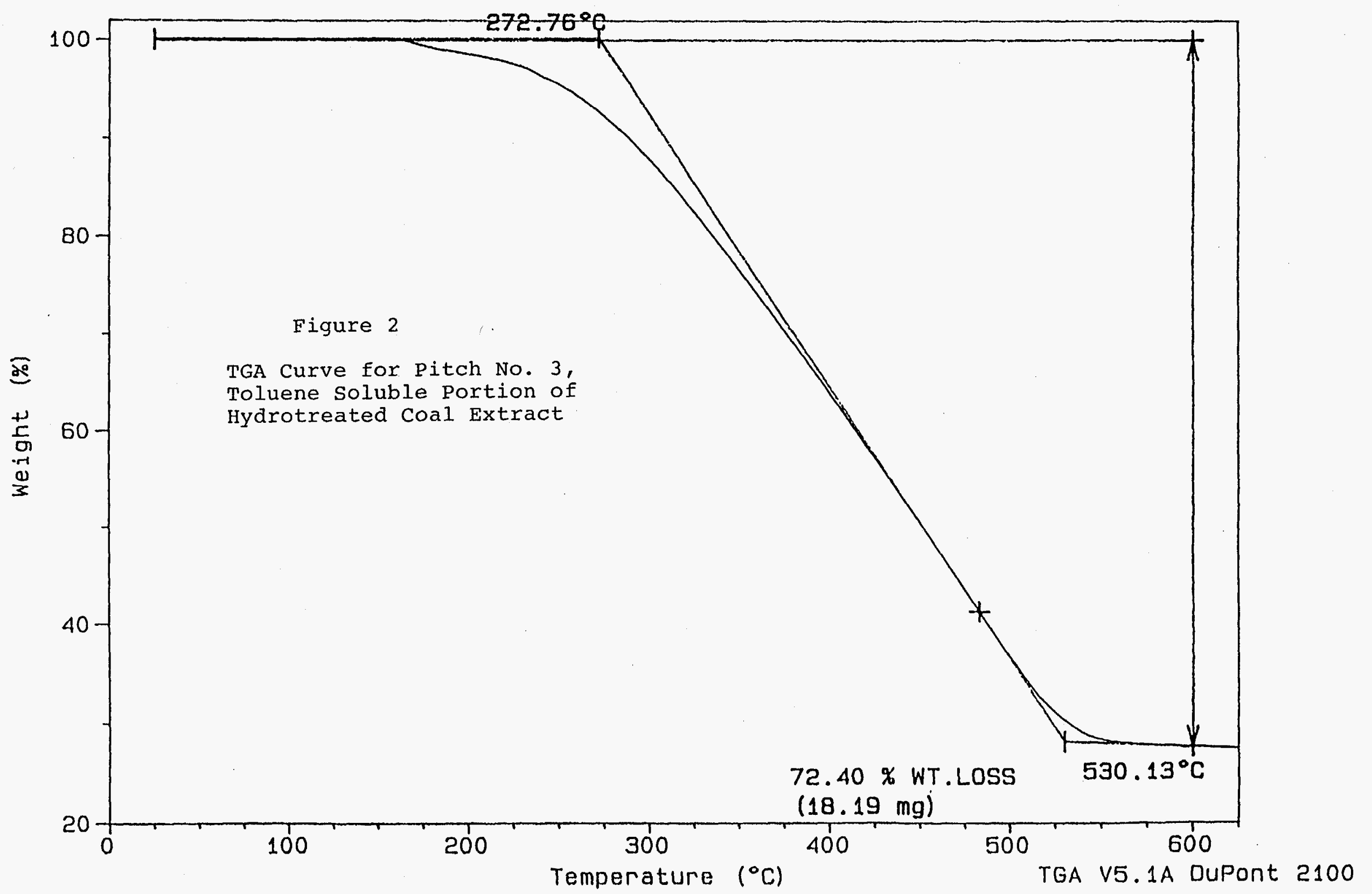




\section{Table IV}

Analyses of Pitches Evaluated in $50 \mathrm{~mm}$ Diameter Molded Anodes

\begin{tabular}{|l|c|c|c|c|}
\hline \multicolumn{1}{|c|}{ Number } & P-1 & P-2 & P-3 & P-4 \\
\hline Type & $\begin{array}{c}\text { Coal Tar } \\
\text { Standard }\end{array}$ & $\begin{array}{c}\text { Petroleum } \\
\text { Standard }\end{array}$ & $\begin{array}{c}\text { Hydrogenated } \\
\text { Coal-Extract }\end{array}$ & $\begin{array}{c}\mathbf{2 0 \%} \text { P-3 } \\
\mathbf{8 0 \%} \text { P-1 }\end{array}$ \\
\hline SP, ${ }^{\circ} \mathrm{C}$ & 111.6 & 112.0 & 119.2 & 114.5 \\
\hline TI, wt.\% & 30.3 & 3.2 & 11.5 & 26.5 \\
\hline Ql, wt.\% & 14.7 & 0.1 & 0.5 & 11.9 \\
\hline$\beta-R, w t . \%$ & 15.6 & 3.1 & 11.0 & 14.6 \\
\hline MCC, wt.\% & 57.8 & 46.9 & 50.7 & 57.3 \\
\hline Density, g/cm ${ }^{3}$ & 1.33 & 1.22 & 1.21 & 1.31 \\
\hline Ash, wt.\% & 0.24 & 0.03 & 0.07 & 0.20 \\
\hline
\end{tabular}




\section{Table V}

\section{Control and Trial Pitch Baked Anode Characterization}

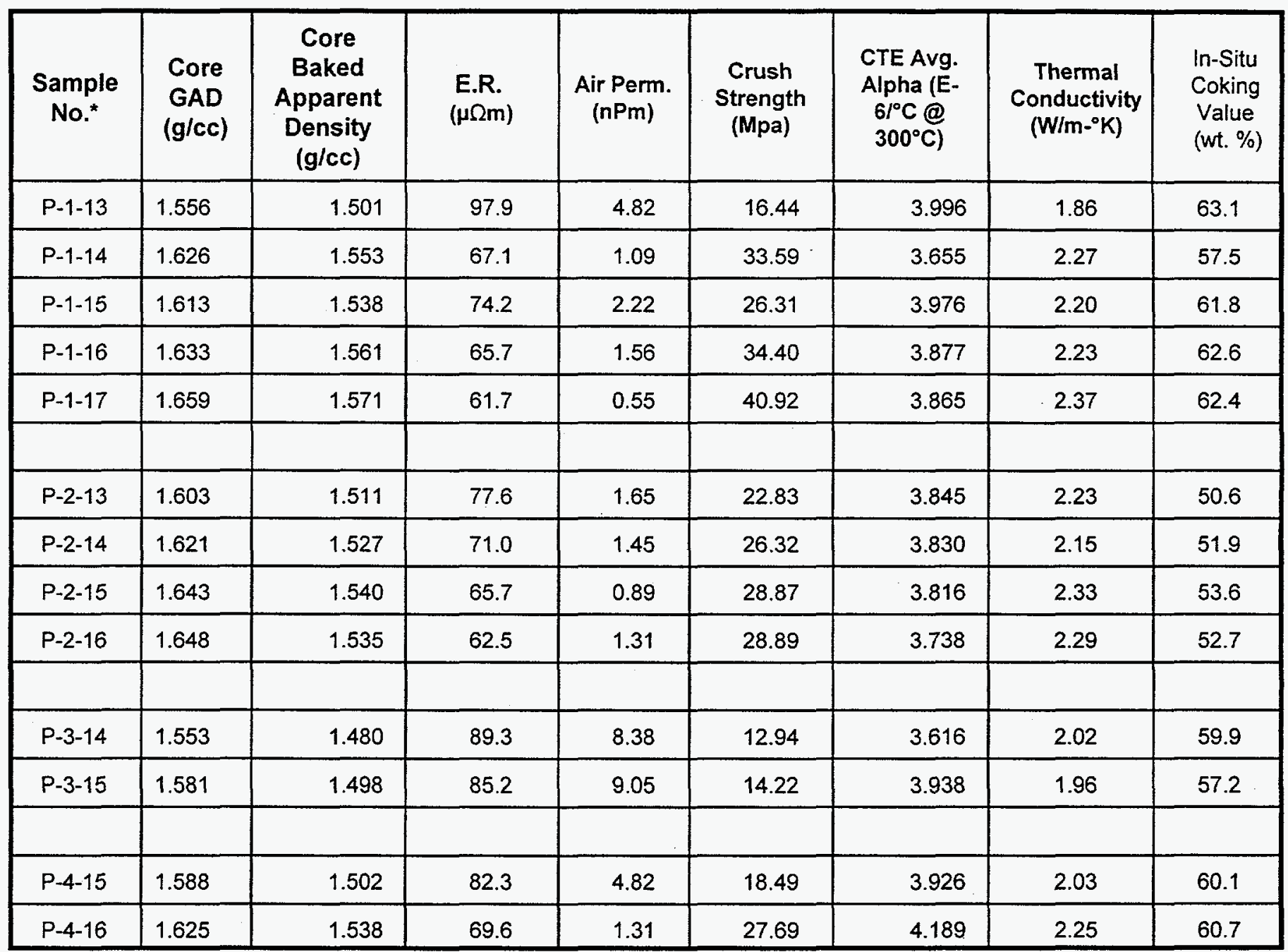

*Sample No. shows the pitch type and the binder level in percent. The two control pitch sample Nos. (P-1 and P-2) are the average of two $50 \mathrm{~mm}$ diameter anodes. The trial pitch samples (P-3 and P-4) are single anodes. 


\section{v. CONCLUSIONS}

- The HC-E pitches have softening points and viscosities that will enable application as binders or impregnants. The low insolubles assure impregnating capability.

- An increase in coking value and a decrease in oxygen and nitrogen contents in the $\mathrm{HC}-\mathrm{E}$ pitches are required for binder and impregnant applications.

- Because of insufficient sample, only two binder levels (14 and 15\%) were investigated for the HC-E experimental pitch in the bench-scale anodes; consequently, the optimum anode binder level could not be determined. Nonetheless, preliminary results are promising.

- The quantity of $20 \%$ of HC-E pitch blended with $80 \%$ of standard coal tar pitch also only permitted two binder levels (15 and 16\%); again, the optimum binder level was not obtained. The performance of the blend pitch is projected to be almost as good as $100 \%$ coal tar pitch.

\section{RECOMMENDATIONS FOR FUTURE WORK}

- Obtain sufficient quantities of HC-E samples to enable the forming of vibrated 4-inch diameter anodes at a minimum of six binder levels.

- Larger samples will also allow preparation of several blends of HC-E pitch and coal-tar pitch for optimization study.

- Extract hydro treatment optimization as related to anode properties should be studied.

- The initial evaluation of extract and HC-E materials as feedstocks for other binders, oils and cokes should be performed. 


\section{FIGURE 3 \\ GREEN APPARENT DENSITY}

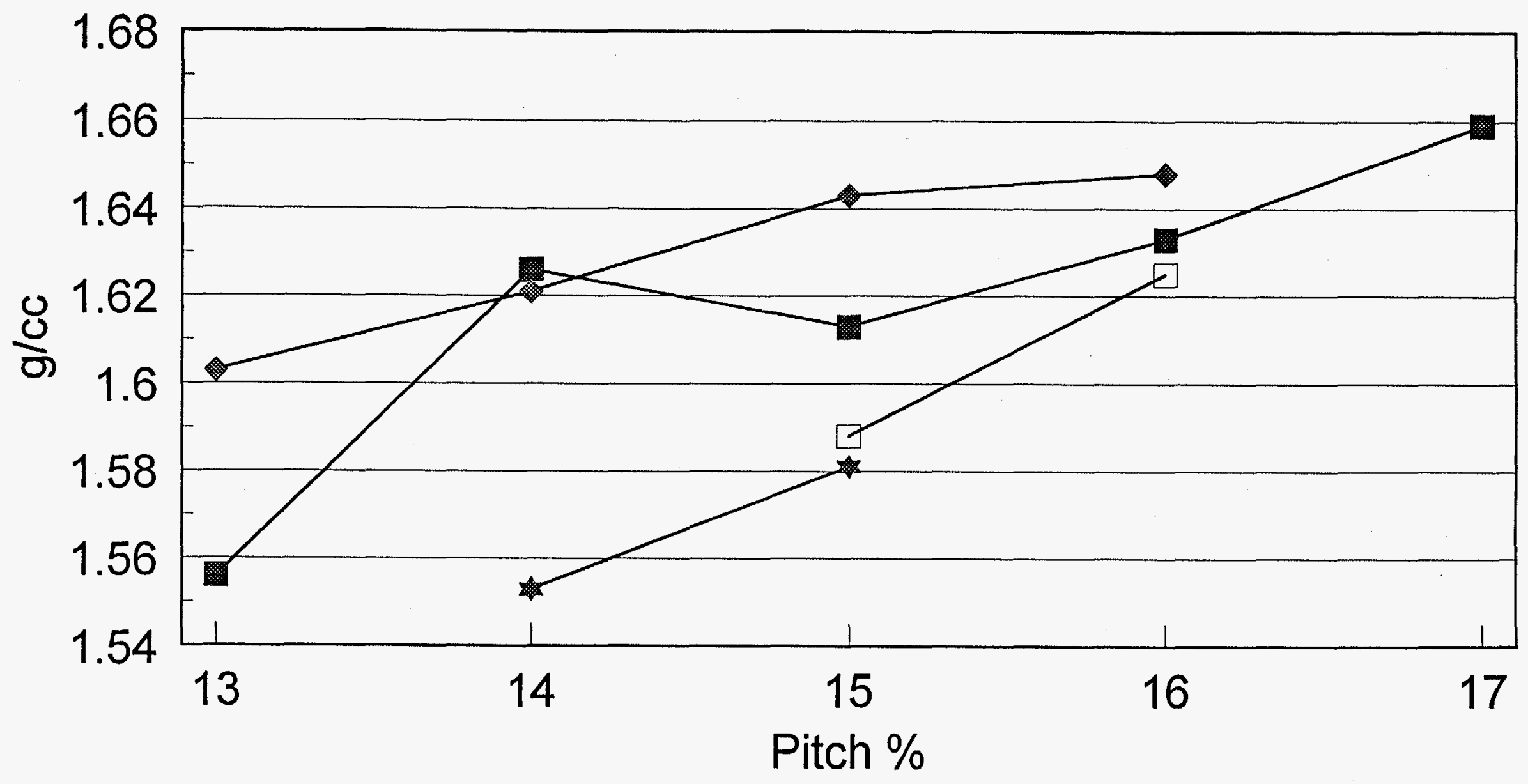

\begin{tabular}{|ccccc|}
\hline P-1 & P-2 & P-3 & P-4 \\
Coal Tar & Petroleum & HC-E & $20 / 80$ \\
\hdashline & - & & & \\
\hline
\end{tabular}




\section{FIGURE 4 BAKED APPARENT DENSITY}

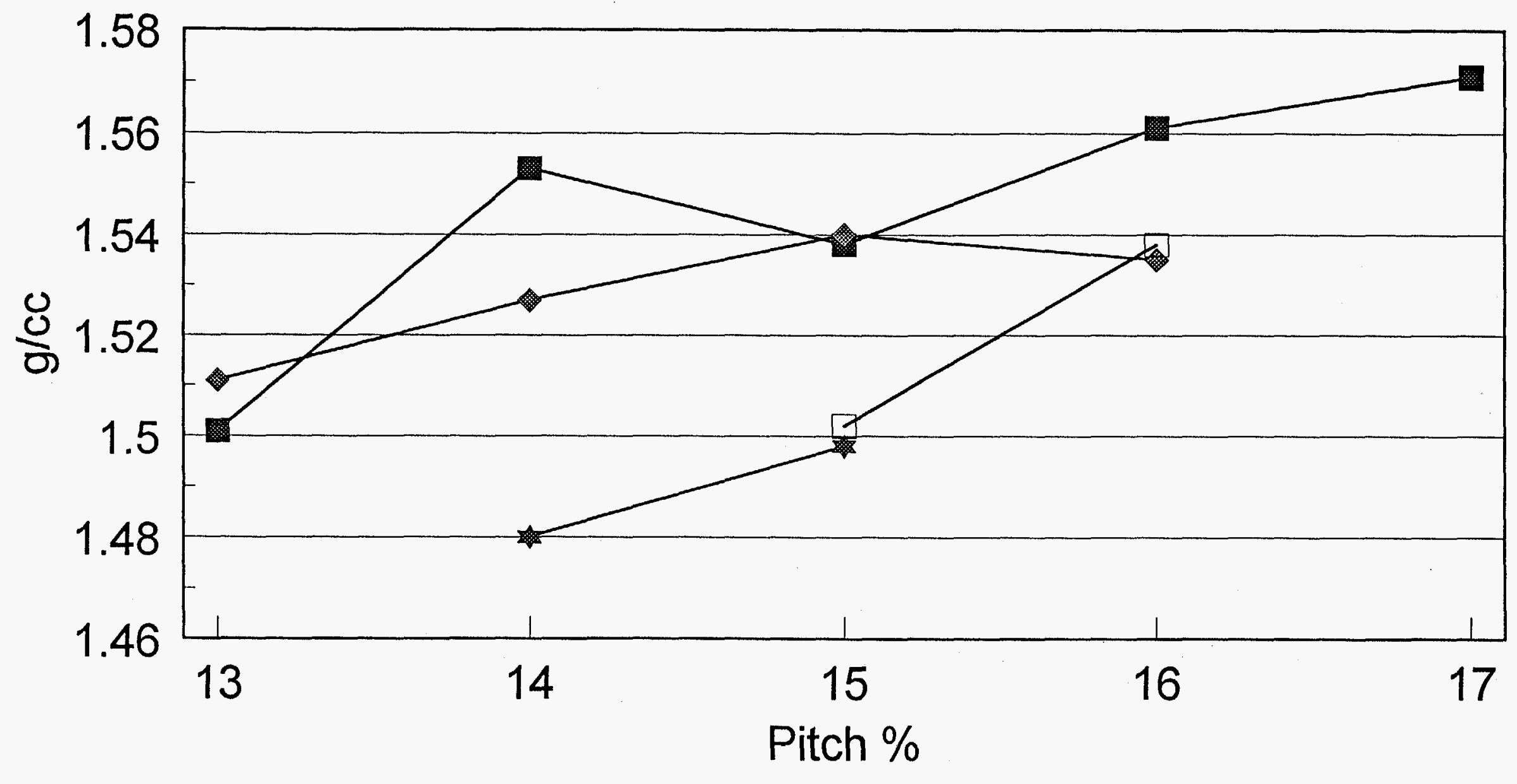

\begin{tabular}{|cccc|}
\hline P-1 & P-2 & P-3 & P-4 \\
Coal Tar & Petroleum & HC-E & $20 / 80$ \\
\hline & & & $\square$ \\
\hline
\end{tabular}




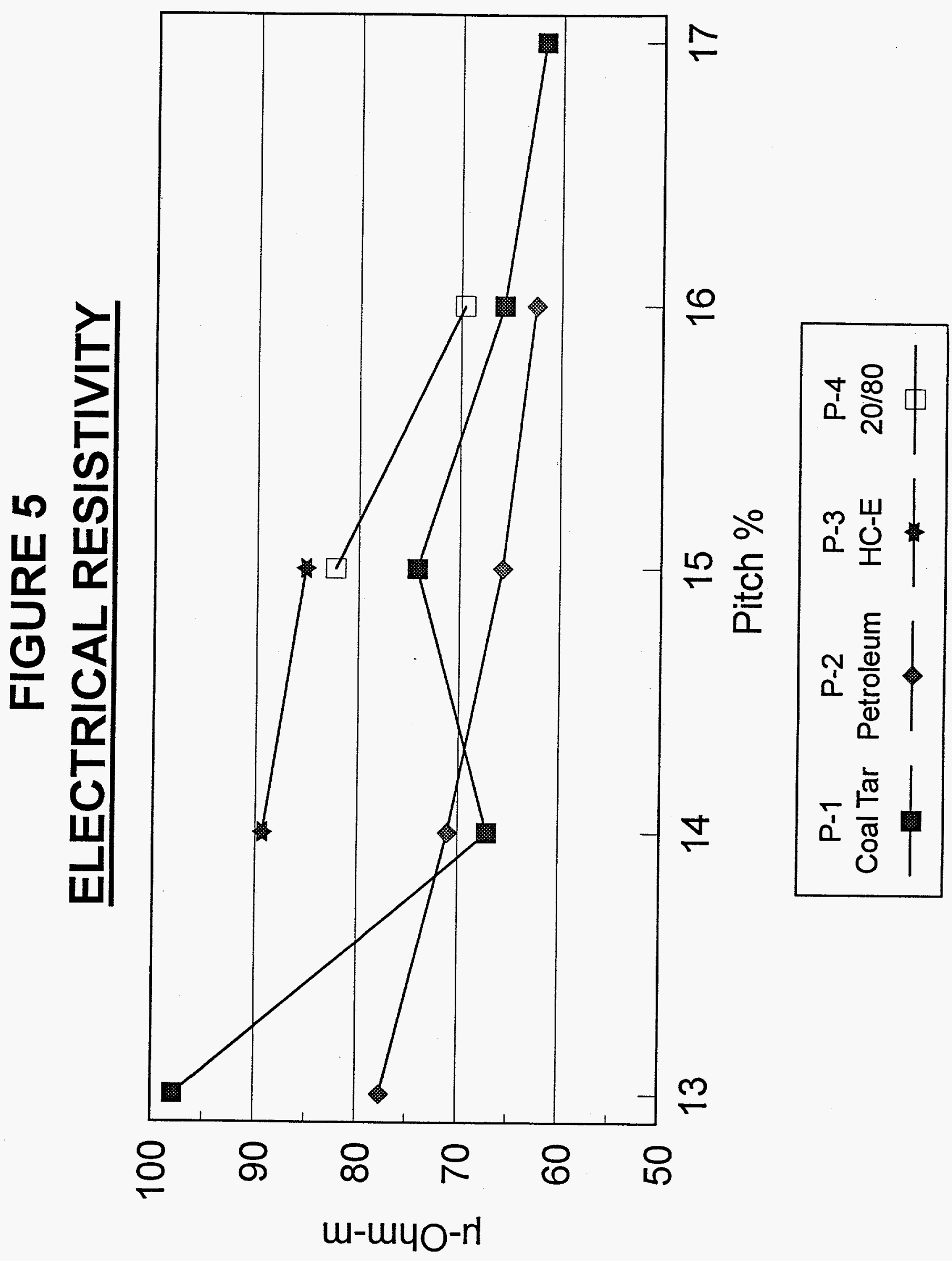




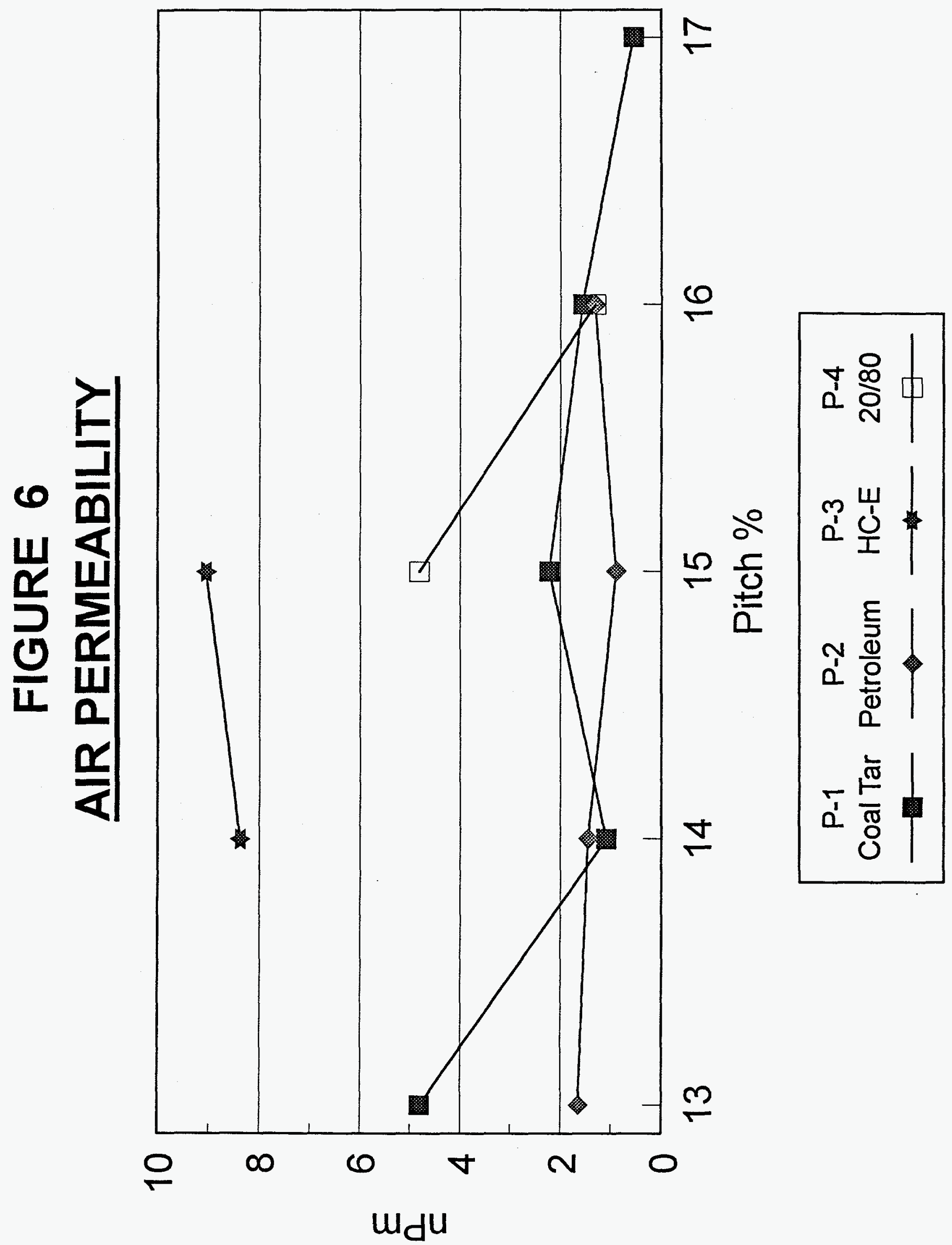




\section{FIGURE 7 \\ COMPRESSIVE STRENGTH}

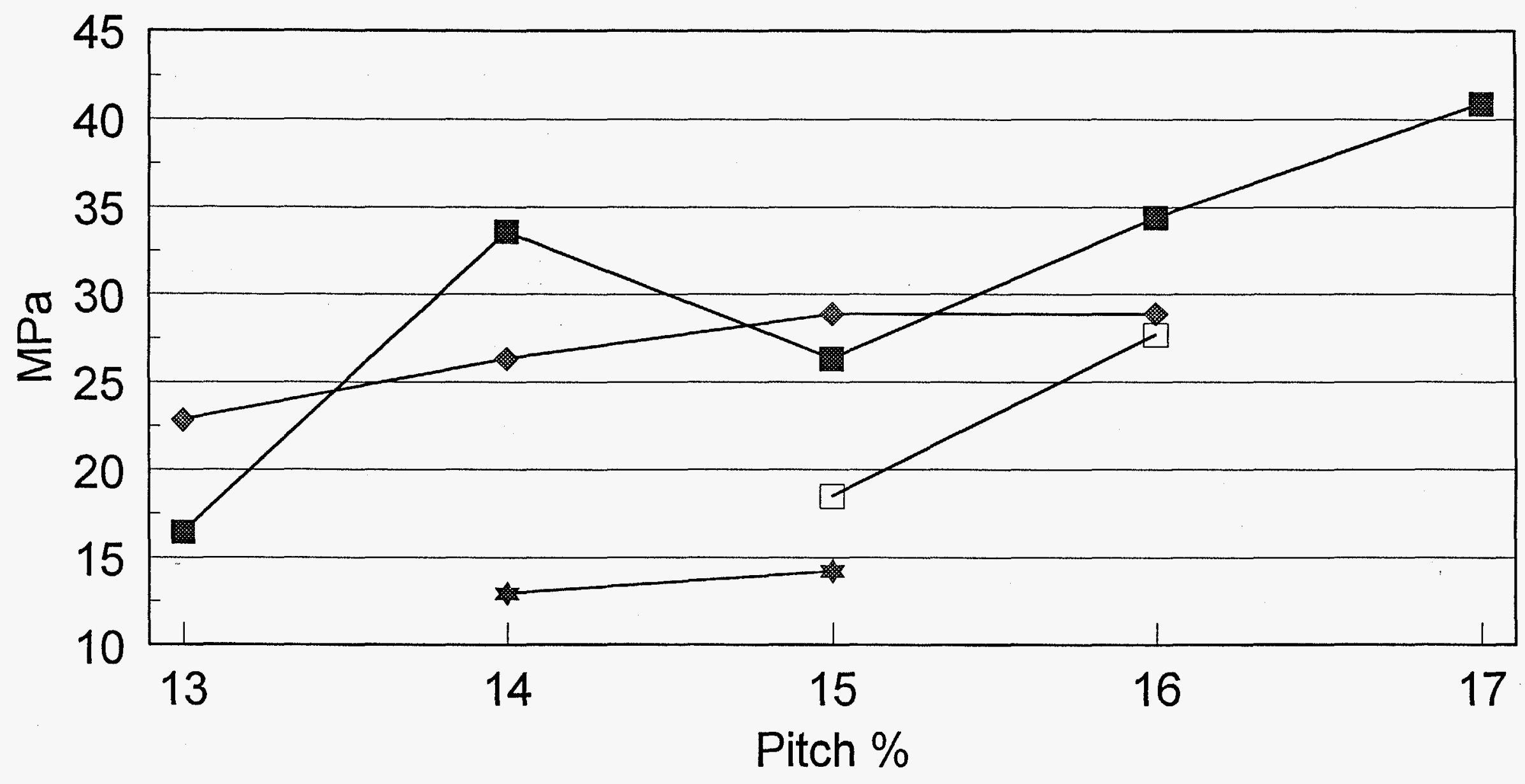

\begin{tabular}{|cccc|}
\hline P-1 & P-2 & P-3 & P-4 \\
Coal Tar & Petroleum & HC-E & $20 / 80$ \\
$\square$ & $\square$ & & $\square$ \\
\hline
\end{tabular}




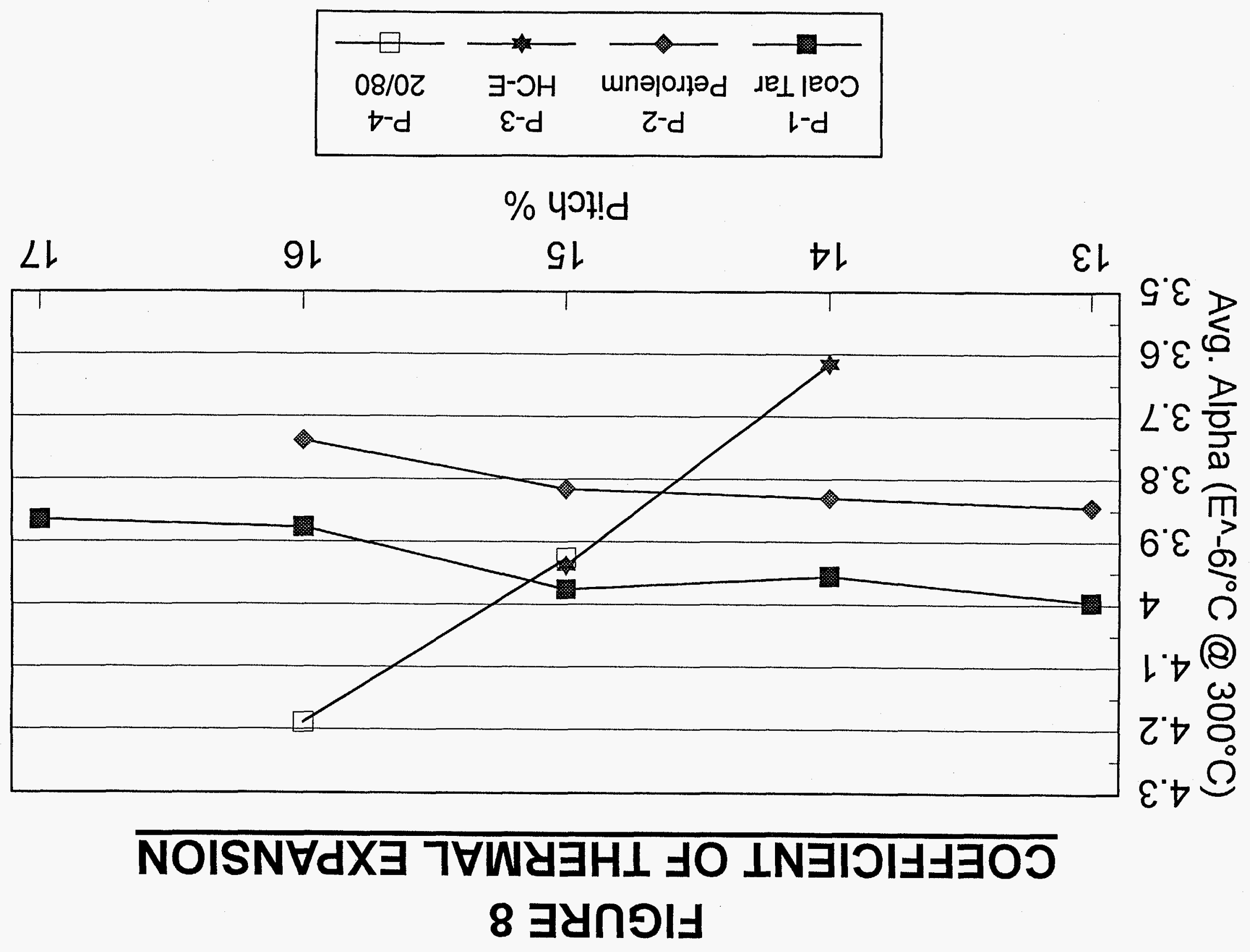


FIGURE 9

\section{THERMAL CONDUCTIVITY}

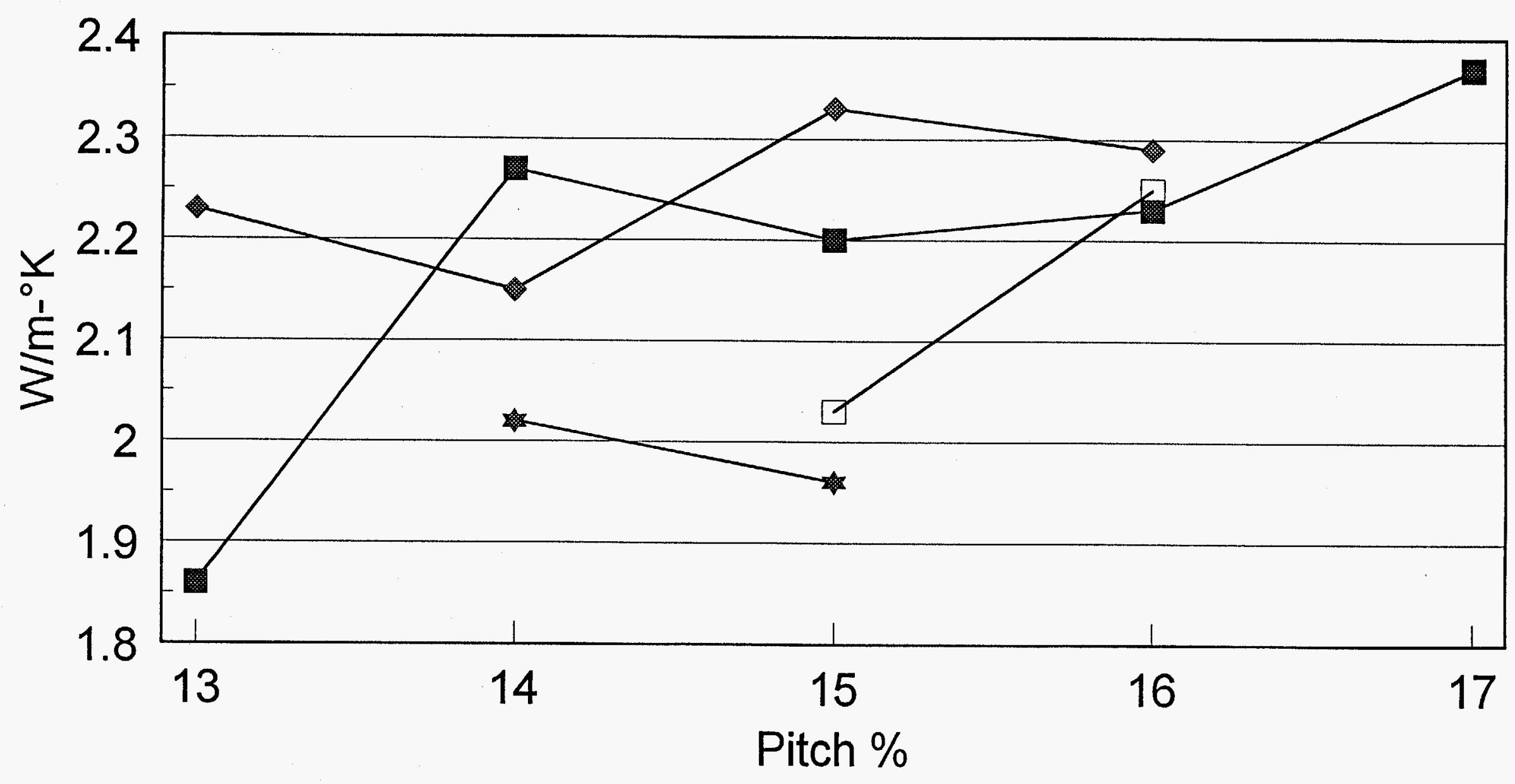

\begin{tabular}{|c|c|c|c|}
\hline P-1 & P-2 & P-3 & P-4 \\
\hline Coal Tar & Petroleum & HC-E & $20 / 80$ \\
\hline-1 & $\rightarrow$ & $\longrightarrow$ & $\square$ \\
\hline
\end{tabular}


AIR PRODUCTS AND CHEMICALS

Attn: S. W. Dean

P.O. Box 538

Allentown, PA 18105

AMOCO PERFORMANCE PROD. INC.

Attm: G. V. Deshpande

4500 McGinnis Ferry Road

Alpharetta, GA 30202-3944

\section{CANADA CENTER FOR MINERAL} \& ENERGY TECHNOLOGY

Attn: R. Winton Revic, Mahi Sahoo

568 Booth Street

Ottawa, Ontario

Canada K1A OG1

DEPT. OF ENERGY

Office of Basic Energy Sciences

Materials Science Division

Attn: H. M. Kerch

ER-131, 19901 Germantown Rd

Germantown, MD 20874-1290

DOE - Pittsburgh Energy Tech. Ctr.

Attn: A.L. Baldwin, G.V. McGurl, T.M. Torkos

P.O. Box 10940

Pittsburgh, PA 15236

ELECTRIC POWER RES. INSTITUTE

Attn: W.T. Bakker, J. Stringer

P.O. Box 10412

3412 Hillview Avenue

Palo Alto, CA 94303

\section{ALCOA TECHNICAL CENTER}

Atm: D. L. Belitskus

100 Technical Drive

Alcoa Center, PA 15069-0001

BABCOCK \& WILCOX

Domestic Fossil Operations

Attn: M. Gold

20 South Van Buren Avenue

Barberton, $\mathrm{OH} 44023$

\section{DEPT. OF ENERGY}

DOE Oak Ridge Operations

Attn: Assistant Manager for Energy R\&D

P. O. Box 2001

Oak Ridge, TN 37831

\section{DOE MORGANTOWN ENERGY}

TECH. CTR.

Atn: R.C. Bedick, D.C. Cicero, F.W. Crouse, Jr, N.T. Holcombe,

W.J. Huber, J.E. Notestein

P. O. Box 880

Morgantown, WV 26505

DOW CORNING CORP.

Attn: H. Atwell

3901 S. Saginaw Road

Midland, MI 48686-0995
AMA RES \& DEV CENTER

Attn: T. B. Cox

5950 McIntyre Street

Golden, CO 80403
BRITISH COAL CORP. Coal Technology Dev. Div. Attn: J. Oakey Stoke Orchard, Cheltenham Glocestershire, England GL52 4ZG
DEPT. OF ENERGY

DOE Oak Ridge Operations

Attn: M. H. Rawlins

P. O. Box 2008

Bldg. 4500N, MS 6269

Oak Ridge, TN 37831

DEPT. OF ENERGY

OFFICE OF FOSSIL ENERGY FE-72

Attn: J. P. Carr

19901 Germantown Road

Germantown, MD 20874-1290
EC TECHNOLOGIES

Attn: D. J. Kenton

3614 Highpoint Drive

San Antonio, TX 78217

\author{
EUROPEAN COMMUNITIES \\ JOINT RESEARCH CENTRE \\ Petten Establishment \\ Atm: M. Van de Voorde \\ P. O. Box 2, 1755 ZG Petten \\ The Netherlands
}

FIBER MATERIALS, INC.

Aton: C. Baker

5 Morin Street

Biddeford, ME 04005-4497 
GA TECHNOLOGIES INC.

Attn: T. D. Gulden

P. O. Box 85608

San Diego, CA 92138

KOPPERS INDUSTRIES, INC.

Attn: E. R. McHenry

1005 William Pitt Way

Pittsburgh, PA 15238

\section{NATIONAL MATERIALS ADVISORY} BOARD

National Research Council

Attn: K.M. Zwilsky

2101 Constitution Avenue

Washington, DC 20418

SANDIA NATIONAL LABORATORIES

Attn: G.A. Carlson

Dept 6211, MS 0710

Albuquerque, NM 87185
GAS RESEARCH INSTITUTE

Attn: H.S. Meyer

8600 West Bryn Mawr Avenue

Chicago, II 60631

\section{IDAHO NATIONAL ENGINEERING LAB \\ Attn: B. H. Rabin \\ P. O. Box 1625 \\ Idaho Falls, ID 83415}

OAK RIDGE NATIONAL LAB

Attn: T.D. Burchell, T.P. Carlson, N.C. Cole, R.R. Judkins, M.R. Upton, F.D. Johnson (5 XX)

P.O. Box 2008

Oak Ridge, TN 37831

SHELL DEVELOPMENT CO. Attn: L.WR. Dicks

P. O. Box 1380

Houston, TX 77251-1380
GEORGIA INST. OF TECH. Materials Science \& Eng. (0245)

Attn: T. L. Stan

Bunger-Henry Bldg., Room 276

Atlanta, GA 30332-0245
OFFICE OF NAVAL RESEARCH Attn: S.G. Fishman Code 431, 800 N Quincy Street Arlington, VA 22217
TENNESSEE VALLEY AUTHORITY Energy Demonstration \& Technology Attn: C.M. Huang MR2N58A

Chattanooga, TN 37402-2801
THE NORTON COMPANY High Performance Ceramics Div. Atm: N. Corbin Goddard Road Northborough, MA 01532-1545
THE TORRINGTON COMPANY Advanced Technology Center Attn: W.J. Chmura 59 Field Street Torrington, CT 06790
UCAR CARBON COMPANY, INC.

Attn: I. Lewis 12900 Snow Road

Parma, OH 44130
UNION CARBIDE CORP.

Linde Division

Attn: Harry Cheung

P.O. Box 44, 175 East Park Dr

Tonawanda, NY 14151-0044
UNTTED TECHNOLOGIES RES. CTR Attn: K.M. Prewo MS 24, Silver Lane East Hartford, CT 06108 
UNIVERSITY OF KENTUCKY

Crr. For Applied Energy Research Attn: F. Derbyshire 3572 Iron Works Pike Lexington, KY 40511-8433

WEST VIRGINIA UNIVERSITY Department of Chemical Engineering Attn: A.H. Stiller, J.W. Zondlo, P. G. Stansberry P. O. Box 6101 Morgantown, WV 26506-6101

CONOCO INC.

P. O. Box 2197

Houston, TX 77252-2197

G. Harlacher
UNIV. OF WASHINGTON

Dept of Mats. Sci. \& Eng.

Attn: T.G. Stoebe

101 Wilson, FB-10

Seattle, WA 98195

WEST VIRGINIA UNIVERSITY

NATIONAL RESEARCH CENTER FOR COAL \&ENERGY

Attr: C. L. Irwin

P. O. Box 6064

Morgantown, WV 26506-6064
VIRGINIA POLYTECHNIC INST. \& STATE UNIVERSITY

DepL of Materials Engineering

Attn: W.A. Curtin, K.L. Reifsnider

Blackburg, VA 24601

CONOCO INC.

K. Tacker

P. O. Box 1267

Ponca City, OK 74602 